\title{
NEW GROUP WITH A NEW SPECIES OF THE GENUS EOTETRANYCHUS OUDEMANS (ACARI : TETRANYCHIDAE)
}

\author{
SOHIER I. ABDEL-RAHMAN, ABLAH A. IBRAHIM \\ AND GAMAL A. IBRAHIM
}

Plant Protection Research Institute, ARC, Dokki, Giza

(Manuscript received 16 February 2009)

\begin{abstract}
Currently preminent slides of the tetranychid mite collected from mandarin orange Citrus mandurensis Lour at Wady El Mollak village El-Sharkia Governorate were prepared. Microscopical examination pointed out that mite belongs to the genus Eotetranychus Oudemons, tribe Tetranychini, subfamily Tetranychinae of the family Tetranychidae. Herein the mite was drawn and identified. According to the terminology of this genus, the mite has the caudal pair of para-anals (the post anal setae) present together with having the empodium consisting of three pairs of hairs, the peritreme is strong hocked distally. The dorsal striae of the female as well as male transverse between the third pair of dorsocentral hysterosomsals and the sacrals. The dorsal setae are exceeding the distance between their bases. Genital flap with transverse striae anterior the genital opening .

Revision of the literature, it was clear that the mite morphological of the mite characters seemed to be new to the science and belonging to a new group of the genus Eotetranychus Oudemans.
\end{abstract}

\section{INTRODUCTION}

In 1913 Oudemans erected the genus Eotetranychus on the type species

Trombidium tiliarum Herman 1804. Subsquently, various authors placed the newly discovered tetranychid species under the genus Eotetranychus. Oudemans, (Jeppson et al. 1975) .

Accordingly, various species which were described from different host plants in different countries seemed to have the main charactertics of this genus. Oudmans 1931, McGregor 1943, Pritchard and Baker 1955 , Tuttle and Baker 1968 , Meyer 1987, Baker and Tuttle 1994, Bolland et al 1998, Migeon et al 2004 deal with this genus . 
Pritchard and Baker (1955) established six groups namely Caribbeanae, Multidigituli, Lebocerdi , Steganus , Clitus and Tiliarium group on the basis of the type of striae of the genital flap, then after, Meyer (1987) divided the species of this genus into four groups.

During the present work a tetranychid mite collected from mandarin tree Citrus mandurensis Lour at Wadi El-Mollak village El-Sherkia Governorate proved to represent a new species and new group of the genus Eotetranychus Oudemans.

\section{GROUP Egypticus}

This group is unique in having propodosmal dorsum covered with a longitudinal median striae encircled by U-shaped. Hysterosomal dorsum ornamented by transverse striae anteriorly and arch-like ones posterioly. Dorsocentral and dorsolateral setae being longer than the distance between their basis . Striae of the genital flap and those anterior to it being arch-like. Aedeagus with distal part of the aedeagus being narrowly short, bent upward, with small knob having a minute anterior and posterior angulation .

\section{MATERIALS AND METHODS}

During a survey of the tetnanychids at Wady El Mollak village, El-Sharkia Governorate mites were collected from mandarin tree Citrus mandurensis Lour. The collected individuals were singly mounted in Hoyer's medium on glass slides and carefully examined, identified according the terminology of Pritchard and Baker 1955. The mite identification assured to be a new group and new species of the genus Eotetranychus Oudemans.

Examination of the specimens collected showed the taxonomic values such as chelicera, palp, chaetotaxal pattern of the dorsum and ventrum in addition those of the legs . 


\section{RESULTS AND DISCUSSION}

Female : The newly emerged female usually pale reddish yet transformed to dark red when getting old. Body oval $736^{\mu m}$ long including the gnathosoma, $529^{\mu m}$ idiosoma with a broad width $425^{\mu m}$. Dorsal view reticulated with striae, being longtudinal in the medial part of propodasoma, which usually encountered by u-shaped ones, with an oblique ones laterally (Fig. $1 \mathrm{~A}$ ). Striae between $\mathrm{D}_{1}$ and $\mathrm{D}_{2}$ transverse, longitudinal in the median area of each of $D_{3}$ and $D_{4}$, transverse in median area between them. Humerals nearly subequal any of the propodosomals. Dorsum bearing thirteen setae, of which 3 on propodosoma. Setae $D_{1}-D_{3}$ and $L_{1}-L_{4}$ exceeding the distance between them , $D_{4}$ hardly reaching the bases, $D_{5}$ (the clunals), the humerals (h) nearly subequals any of the propodosomals. Palp with a simple long seta on the genu, tibia with two simple setae and a distinct claw, palpal tarsus having 3 simple short setae, rather distinct terminal digit and 2 solenidia (Fig. 1 B). Peritreme sussage like anchor shaped distally, arcute just before reaching the stigma, composed of thirteen segments (Fig. $1 \mathrm{C}$ ) . Genito anal area with transverse stria anterior to the genital opening, bearing one pair of long genital setae, two pairs of short anals and two pairs para anals (Fig 1. D).

Leg chaetotaxal formulae as follows : caxae $2-2-1-1$, trochanters 1-1-1-1, fumora 10-5-4-4, genua 5-5-4-4, tibiae 10- 7-6-7, tarsi $14+(2)$ duplex setae , $13+(1)$ duplex seta $-01-11$, true claws pad like, each with a pair of tenent hairs . Empodial venteral element consisting of three pairs of rather long tenent hairs (Fig. 1 E). 


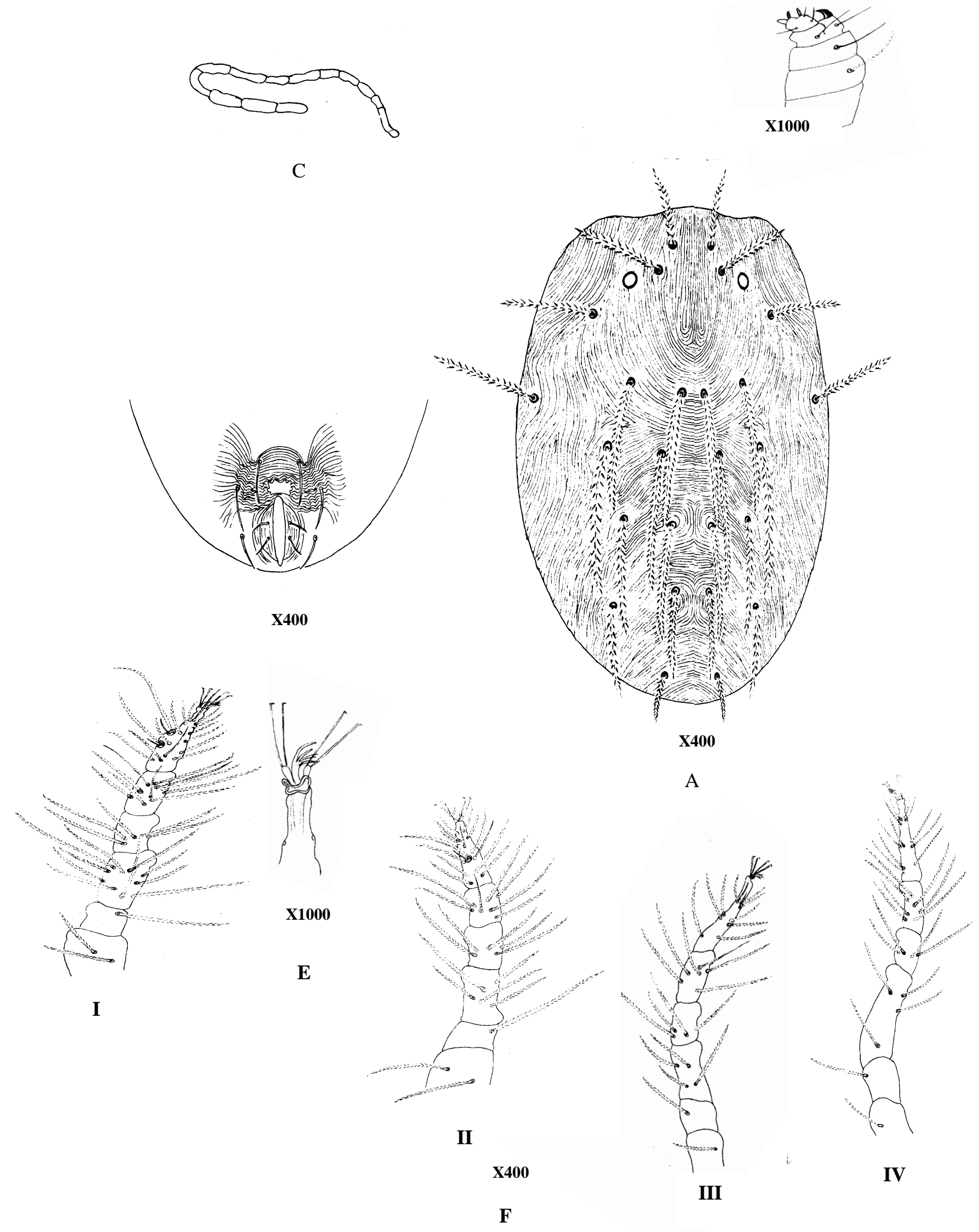

Fig. 1 Eotetranychus egypticus n.sp female (A) Dorsal view (B) Palp (C) Pritreme (D) Genital anal opening (E) Tarsus of leg 1 (F) legs 1 - IV 
Male : Similar to the female but differs in the following characteristics. Body length $448^{\mu m}$ including gnathosoma $\left(103^{\mu m}\right)$ and $230^{\mu m}$ width, palpal genu with a short lanceolate finely serrate seta, tibia having a small claw and three simple setae, palpal tarsus bearing two short simple setae, terminal sensillum slender and 2 solenidia . Aedeagus turns dorsal with about right angle, knob formes an angle with the axis of the shaft, terminal knob about fourth the length of the dorsal margin of the shaft, anterior and posterior projection of the knob acute,
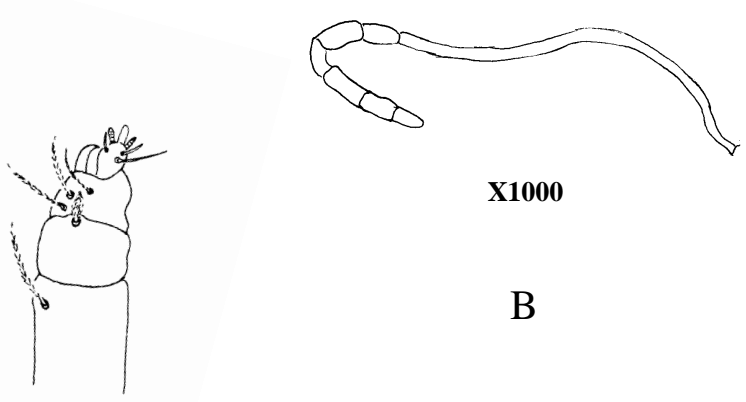

$\mathbf{X 1 0 0 0}$

B

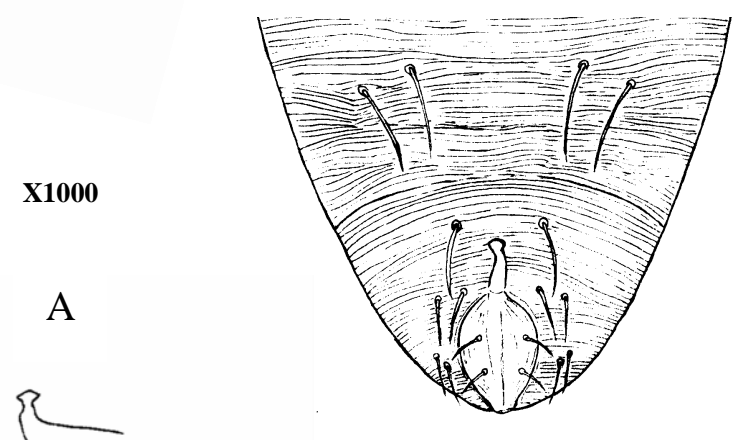

$\mathbf{X 1 0 0 0}$

$\mathrm{D}$

$\mathbf{X} 400$

$\mathrm{C}$

Fig. 2. Eotetranychus egypticus n.sp male. (A) Palp (B) Peritreme (C) Caudoventral aspect of the opisthosome (D) Aedeagus

Holotype: A female collected from Citrus mandurensis lour on February 21, 2007 at Wady El-Mollak El-Sharkia Governorate, by the third author and put in the collection of plant protection research.

Allotype : A male collected from the above mentioned host plant and locality.

Paratypes: Five females and five males collected from orange Citrus ourantium lour from the same locality, on March 23,2007. 


\section{REFERENCES}

1. Baker, E. W. and D. M. Tuttle. 1994. A Guide to the Spider Mites (Teranychidae) of the United States . Indira Publishing House, 347PP. West Bloomfield (US). 347 pp..

2. Bolland, H. R., J. Gutierrez and C. H. W. Fletchtmann. 1998. World Catalogue of the Spider Mite Family (Acari : Teranychidae.) .International Journal of Acarology 30, 143-152 Brill, Leiden (NL).

3. Hermann , J. F. 1804. Mémoire, Aptérologique, 144 PP. Strassbourg.

4. Jeppson, L. R., H. H. Keifer and E. W. Baker. 1975. Mites Injurious to Economic Plants. 1- 614 University of California Press, Berkeley (US).

5. McGregor, E. A. 1943. A new spider mite on citrus in South-Western California. Proceedings of the Entomological Society of Washington 45, 127-129.

6. Meyer, M. K. P. 1987. African Tetranychidae- with reference to the world fauna. Entomology Memoir, Department of Agriculture and Water Supply, Republic of South Africa 69, 1- 175 .

7. Oudemans, A. C. 1931. Acarologische, Aanteekeningen C.VI. Ent. ber., Amst., 8 (177) $189-204$.

8. Migeon, A. and H.W. Flechtmann. 2004. First additions and corrections to the World Catalogue of the spider mite family ( Acari Tetranychidae ). Inter-national Journal of Acarology 30, 143-152.

9. Pritchard, A. E. and E.W. Baker. 1955. A Revision of the Spider Mite Family Tetranychidae. Memoirs Series, 2: 1-472 The Pacific Coast Entomological Soci-ety, San Francsico (US) .

10. Tuttle, D. M. and E. W. Baker. 1968. Spider Mites of Southwestern United States and a Revision of the Family Teranychidae. University of Arizona Press, 143PP Tucson (US) . 
مجموعة جديدة ونوع جديد من جنس

\section{Eotetranychus Oudemans}

( اكارى : نترانيكيدى )

سهير إبراهيم عبد الرحمن عبلة عبد الوهاب إبراهيم جمال الدين عبد المجيد ابراهيم

$$
\text { معهر بحوث وقاية النباتات - مركز البحوث الزراعية - الدقى - الجيزة }
$$

تم فحص مزرعـة يوسفى مـن منطقـة وادى المـلاكك محافظــة الثـرقية مصـابة إصـابة شـديدة

باكاروس يتبع فصيلة تترانكيدى تم أخذ عينات إلى المعمل بالدقى وتم تحميل شرائح للإناث وللذكور على جنبها وتم فحص هذه الثـرائح وتصنيفها وكذا عمل مراجعة لمجاميع هذا الجنس فتبين وجود مجموعة جديدة سميث Egypticus group ونوع جديد سمى Eotetranychus egypticus n.sp وتم

$$
\text { وصف إناث وذكور النوع الجديد . }
$$

